ECLETICA A

www.scielo.br/eq

www.ecletica.iq.unesp.br

Volume 33, número 3, 2008

\title{
Spectrophotometric determination of arsenic in soil samples using 2-(5-bromo-2-pyridylazo)-5-di-ethylaminophenol (Br- PADAP)
}

\author{
S. F. P. Pereira ${ }^{*}$, S. L. C. Ferreira ${ }^{2}$, G. R..Oliveiral ${ }^{1}$ D. C. Palheta ${ }^{3}$, B. C. Barros ${ }^{4}$ \\ ${ }^{1}$ Laboratório de Química Analítica e Ambiental - Cidade Universitária José da Silveira Neto, 66075-100, Belém-PA-Brasil \\ ${ }^{2}$ Instituto de Química, Universidade Federal da Bahia, Salvador-Bahia-Brasil, CEP 40170-290, \\ ${ }^{3}$ Instituto de Saúde e Produção Animal, Universidade Federal Rural da Amazônia - Belém - Pará - Brazil \\ ${ }^{4}$ Laboratório Central - LACEN - Secretaria da Saúde, Belém-Pará-Brasil, CEP 66077-530 \\ *simonefp@ufpa.br
}

\begin{abstract}
In this paper, a new, simple and sensitive method for arsenic determination in soil is proposed. This is based on the reduction of silver (I) and iron (III) ions by arsine followed by a complexation reaction of iron (II) with the spectrophotometric reagent Br-PADAP 2-(5-bromo-2-pyridylazo)5-di-ethylaminophenol. Arsenic determination with a Sandell's sensitivity of $3.110^{-4} \mathrm{~cm}^{-2}$, linear range from $0.1 \mu \mathrm{g} \mathrm{ml}^{-1}$ to $2.0 \mu \mathrm{g} \mathrm{ml}^{-1}\left(\mathrm{r}_{560}=0.9995\right)$, molar absorptivity of $2.4510^{5} 1 \mathrm{~mol}^{-1} \mathrm{~cm}^{-1}$ and a concentration detection limit of $1.4 \mathrm{ng} \mathrm{ml}^{-1}$ (3s) were obtained using a $10 \mathrm{ml}$ sample volume. Selectivity was increased with the use of EDTA as a masking agent. The proposed method was applied for arsenic determination in the presence of several ions amounts in digested soil samples. The results revealed that antimony (III), mercury (II), germanium (IV), platinum (IV) interferes at all analyzed proportions. The interferences can be easily removed by the use of EDTA. Precision and accuracy obtained were satisfactory with a R.S.D. < $5 \%$. Recovery of arsenic in soil samples varied from 95.55 to $102.70 \%$ with a mean of $99.63 \%$. These results demonstrated that the proposed method is applicable for arsenic analysis in different soil samples.
\end{abstract}

Keywords: Arsenic determination; Br-PADAP; spectrophotometry; soil.

\section{Introduction}

Arsenic has been reported to be a toxic ion; its presence in the soil can affect drinking water due to high environmental concentrations in some regions of the world [1]. Arsenic is the 20th most abundant element in the earth's crust, where the weathering of arsenic-containing minerals, agricultural activities have produced a concentration of approximately $10 \mathrm{mg} \mathrm{kg}^{-1}$ in soils [2]. Arsenic concentrations in US surface soils are in the range of $0.1-97.0 \mathrm{mg} \mathrm{g}^{-1}$ with the major source being a result of human activities [3].

Arsenic may accumulate in soil through the use of arsenical pesticides, leaching of wood preservatives, application of fertilizers, irrigation and dust from the burning of fossil fuels, and the disposal of industrial and animal wastes [4]. Anthropogenic influence on arsenic levels in soils depends on the intensity of human activity, distance from pollution sources, and pollutant dispersion pattern [5]. 
There are several accepted analytical methods currently available for arsenic measurement in environmental samples. These include hydride generation atomic absor-ption spectrometry (HGAAS) [6], neutron activation [7], inductively coupled plasma atomic emission spectrometry (ICPAES) [8]. However, these methods require comparatively expensive equipment and are not readily amenable to portable instrumentation. Hydride generation methods are at the present the most popular techniques for arsenic separation prior to its quantification at low concentrations in a wide range of materials [9, 10]. Hydride generation dates back nearly 150 years [11]. The most widely used spectrophotometric method for separation and determination of arsenic is based on its evolution as arsine gas from a hydrochloric acid solution followed by a spectrophotometric measurement using silver diethyldithiocarbamate (SDDC) as the color forming reagent $[12,13,14,15]$. The SDDC method presents some disadvantages as the unpleasant piridina odor and the low stability of the formed complex.

The Br-PADAP has been proposed as a good chromogenic reagent due to its high sensitivity and stability. In recent years it has been used for Fe (II) determination [16, 17] with many advantages over ferrozine and 1,10-phenanthroline. Br-PADAP reacts with iron (II) and iron (III) cations and the iron (III) complex is decomposed totally in presence of EDTA, the excess of $\mathrm{AgNO}_{3}$ is removed from the solution by addition of the $\mathrm{Cl}^{-}$ions [18]. This current paper describes a simple, rapid and accurate method applied for arsenic determination in soil samples using $\mathrm{Br}$ PADAP as a chromogenic reagent.

\section{Experimental}

Solutions, reagents and samples. High purity analytical grade reagents were used. Double distilled deionised water was used throughout the assays (MilliQ system, 10.5 $\mathrm{M} \Omega \mathrm{cm}^{-1}$ ). $\mathrm{HNO}_{3}$ (Merck) and $\mathrm{H}_{2} \mathrm{SO}_{4}$ (Merck) were used for ferric solution and acid digestion.

Absorbing solution. All substances were prepared by mixing equal volumes of $0.1 \mathrm{M}$ silver nitrate (Aldrich) and $0.00125 \mathrm{M}$ ferric solution.

Standard solution of Br-PADAP (Fluka, Buchs, Switzerland). Was prepared by dissolving
$0.075 \mathrm{~g}$ of Br-PADAP in ethanol plus $20 \mathrm{~g}$ triton$\mathrm{X} 100$ (Aldrich), diluting it to $250 \mathrm{ml}$ in ethanol PA (Aldrich).

Buffer solution. Was prepared by dissolving $2.86 \mathrm{ml}$ of acetic acid (Merck) and $4.10 \mathrm{~g}$ sodium acetate (Merck) in water, diluting it to $100 \mathrm{ml}$.

Developing solution. Prepared by adding $500 \mu \mathrm{l}$ of sodium chloride $0.2 \mathrm{M}$ (Merck), $500 \mu \mathrm{l}$ of an acetate buffer ( $\mathrm{pH} 4.75), 1000 \mu \mathrm{l}$ of a 0.03 $\%(\mathrm{~m} / \mathrm{v})$ Br-PADAP standard solution and 1000 $\mu \mathrm{l}$ of a $0.20 \%(\mathrm{~m} / \mathrm{v})$ EDTA (Merck), respectively after arsine generation.

Ferric solution. Prepared by dissolving ferric ammonium sulfate (Aldrich) in a $3.00 \%$ $(\mathrm{v} / \mathrm{v})$ sulfuric acid solution.

Sodium borohydride (III) solution. A $10.00 \%(\mathrm{~m} / \mathrm{v}) \mathrm{NaBH}_{4}$ (Aldrich) solution was prepared in a $2.00 \%(\mathrm{~m} / \mathrm{v}) \mathrm{NaOH}$ solution (Aldrich) before use [19].

Arsenic stock solution (1000 $\left.\mu \mathrm{g} \mathrm{g}^{-1}\right)$. Prepared by dissolving $1.3200 \mathrm{~g}$ of arsenic trioxide (Carlo Erba) in $10 \mathrm{ml}$ of water plus $4 \mathrm{~g}$ of sodium hydroxide and diluting it to $1000 \mathrm{ml}$ with water.

\section{Analysis procedure}

Arsine was generated by placing a suitable aliquot of sample containing from 0 to $2.0 \mu \mathrm{g}$ arsenic into a flask, containing $25 \mathrm{ml}$ of $1: 1$ hydrochloric acid and $75 \mathrm{ml}$ of water, $2 \mathrm{ml}$ of a $15.00 \%$ potassium iodide solution, for As (V)-As (III) reduction. Bath was cooled for 15 minutes in an ice bath, $6 \mathrm{~mL}$ of $\mathrm{NaBH}_{4}$ solution was added by using a peristaltic pump and capillary tubes. Arsine generated from $\mathrm{NaBH}_{4}$ reduction was bubbled into the absorption tube containing $2 \mathrm{ml}$ of an absorbing reagent. Following 15 minutes, 2 $\mathrm{ml}$ of a developing solution was added. This solution was diluted to $10 \mathrm{ml}$ in water, mixed, and centrifuged. After 5 minutes, the formed complex was read at $560 \mathrm{~nm}$ in UV-Vis spectrophotometer.

\section{Soil analysis}

$0.5 \mathrm{~g}$ of a soil sample was dissolved in 10 ml of $\mathrm{H}_{2} \mathrm{SO}_{4} 1: 1$ plus $20 \mathrm{ml}$ of concentrated $\mathrm{HNO}_{3}$; solution was evaporated at a low temperature $\left(<100^{\circ}\right) \cdot \mathrm{HNO}_{3}$ was removed by evaporation to $\mathrm{SO}_{3}$ fumes. Because of a possible presence of organically bound arsenic, a digestion step must be included to ensure conversion of total arsenic to an inorganic form. The cooled residue 
was dissolved in water and made up $100 \mathrm{ml}$ in a standard flask. A $10 \mathrm{ml}$ aliquot was analyzed according to procedures described previously. $1000 \mathrm{ml}$ of a $0.20 \%(\mathrm{~m} / \mathrm{v})$ EDTA was added to eliminate the interferences. Final solution was read at $560 \mathrm{~nm}$ in UV-Vis spectrophotometer.

\section{Results and discussion}

\section{Reduction of Iron (III) with Silver (0)}

Arsenic determination using an indirect method is based on the reduction of silver (I) by arsine $\left(\mathrm{AsH}_{3}\right)$; iron (III) reduction by silver (0) and consequent determination of iron (II) with $\mathrm{Br}$ PADAP in the presence of an excess $\mathrm{Cl}^{-}$ions, EDTA and acetate buffer ( $\mathrm{pH}$ 4.75). The reaction of Br-PADAP with Fe (II), in the presence of EDTA, forms an orange complex (reaction 1-3) in a maximum absorption at $560 \mathrm{~nm}$ and a composition of 1:2 iron (II)-Br-PADAP [20], as follows:

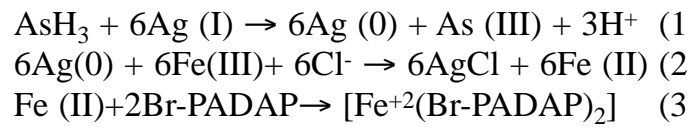

\section{Effect of iron (III) concentrations}

Iron (III) amounts in the order of 35 or 75 $\mu \mathrm{g}$ on iron (II)-Br-PADAP systems has been demonstrated not to affect the analytical curve on the system.

\section{Effect of $p H$}

The influence of $\mathrm{pH}$ on the proposed procedure was investigated, once iron (III) reduction by silver (0) and the formation of the iron (II)-BrPADAP complex can be affected by it [20]. The effect of $\mathrm{pH}$ on the iron (II)-Br-PADAP system was studied elsewhere and the results showed that absorbance signal is maximum and constant in a $\mathrm{pH}$ range from 4.00 to 5.75. In $\mathrm{pH} 3.75$, a small decay in the absorbance signal occurs. In this work, the plausible $\mathrm{pH}$ range is 4.00 to 5.75. The general procedure was developed using an acetate buffer solution at $\mathrm{pH} 4.75$, due to a minimal effect on the absorbance signal.

\section{Effect of the amount of Br-PADAP}

The influence of Br-PADAP amount, ranging from 60 to $900 \mu \mathrm{g}$ was tested; $10 \mathrm{ml}$ of a final solution and $50 \mathrm{ml}$ of a sample solution were used. The maximum signal was obtained with a $300 \mu \mathrm{g}$ of Br-PADAP amount. Above or below this value a significative decay on the absorbance signal occurs.

\section{Effect of the amount of EDTA}

Once Br-PADAP reacts with Fe (II) and $\mathrm{Fe}$ (III), Fe (III) excess elimination is necessary. The studied ranges (100-4000 mg) indicated a significative decay in amounts below or above $2000 \mu \mathrm{g}$ EDTA. The amount recommended is $2000 \mu \mathrm{g}$ for $300 \mu \mathrm{g}$ of Br-PADAP, $70 \mu \mathrm{g}$ Fe (III), $2 \mu \mathrm{g}$ As and $10 \mathrm{ml}$ final solution.

\section{Reagents addition}

The reagents addition of followed an order procedure: EDTA in developing solution must be added after the formation of iron (II)-Br-PADAP complex, which is formed after the reaction between iron (II), Br-PADAP and $\mathrm{pH}$ adjustment. EDTA must be added 2 min after complex formation, in order to guarantee the stabilization of iron (II)-Br-PADAP complex. In vanadium determination, Costa et al. [20] has obtained the same results when analyzing reagents effects on iron (II)-Br-PADAP complex formation.

\section{Characteristics of the complex}

The absorption spectrum of formed iron (II) complex when $1.5 \mu \mathrm{g}$ of arsenic (III) was generated and absorbed in $2 \mathrm{ml}$ of developing solution which was diluted to $10 \mathrm{ml}$ with water, mixed, and centrifuged.

The iron (II)-Br-PADAP complex was formed immediately and was stable for $240 \mathrm{~min}$ utes or more. The Br-PADAP reagent has a low solubility in water but this problem was turned over by the addition of triton-X100. The iron (II)Br-PADAP complex showed a maximum absorption at $560 \mathrm{~nm}$ (at $\mathrm{pH} 4.75)$.

Analytical characteristics and application In the proposed procedure, the calibration curve was linear for arsenic concentration in the range of $0.1 \mu \mathrm{g} \mathrm{ml}^{-1}$ to $2.0 \mu \mathrm{g} \mathrm{ml}^{-1}$, for a final volume of $10 \mathrm{ml}$. The absorbance was read with 1 $\mathrm{cm}$ cells in $560 \mathrm{~nm}$, following Lambert-Beer's law in these ranges.

The equation curves: $\mathrm{A}_{560}=0.311$ conc. As (III) $\mu \mathrm{g}+0.009 ; \mathrm{r}=0.9995$ 
The graph passes through the origin with a molar absortivity of $2.4510^{5} 1 \mathrm{~mol}^{-1} \mathrm{~cm}^{-1}$ and Sandell's sensitivity of $3.1010^{-4} \mathrm{~cm}^{-2}$. The precision of this procedure was expressed by calculating the coefficient of variation (1.46\% standard deviation for ten replicates equals to $0.02 \mu \mathrm{g}$ As). Detection limit (3s level) was $1.4 \mathrm{ng} \mathrm{ml}^{-1}\left( \pm 0.007 \mathrm{ng} \mathrm{ml}^{-1}\right)$ were obtained using a $10 \mathrm{ml}$ sample volume.

\section{Selectivity of the proposed method}

The selectivity of the reaction between $\mathrm{Br}$ PADAP and iron (II) was obtained by the addition of $2.00 \mu \mathrm{g}$ of arsenic in digested soil sample and previously analyzed where several ions $(\mathrm{Sb}, \mathrm{Pb}, \mathrm{Hg}$, $\mathrm{Cr}, \mathrm{Cu}, \mathrm{Au}, \mathrm{Ag}, \mathrm{Bi}, \mathrm{Al}, \mathrm{Co}, \mathrm{Mo}, \mathrm{Te}, \mathrm{Se}, \mathrm{Ge}, \mathrm{Fe}, \mathrm{Pt}$, $\mathrm{P}, \mathrm{N}$ and $\mathrm{S}$ ) was added individually in two proportions (1:1 and 1:25) without the EDTA presence.

The proposed procedure was carried on as follows (Table 1). The interference limit of an ion was taken as the amount at which a change of $\pm 5 \%$ in absorbance of the complex was observed. Results showed that this procedure can be used for arsenic determination in solutions containing most of the cations. The results revealed that antimony (III), mercury (II), germanium (IV) and platinum (IV) interfere at all analyzed proportions. The same procedure was accomplished in the presence of EDTA that was shown efficient in the interferences elimination in the soil analysis.

\section{Method application}

Environmental exposure to arsenic (As) has an important public health concern and is receiving increasing attention following cases of mass contamination in different parts of the world.
However, there is a scarcity of data available on As geochemistry in Brazilian territory, despite the known occurrence of As in some of the more severely polluted areas of Amazon region. [21]. In order to investigate the applicability of this procedure to soil samples, the recoveries of known amounts of arsenic, added to soil samples, were examined by the proposed procedure.

The analyzed soil samples were collected in Manelão Au mining area, located at Bacajá River, a Municipal District of Senador José Porfírio, in the Pará state in Brazil. The arsenic levels found (1.58 - $5.00 \mu \mathrm{g} \mathrm{g}^{-1}$ ) showed that the area doesn't present contamination. Arsenic recovery was measured using a standard addition method. The results are given in Table 2, EDTA was used to eliminate the interferences. Recovery of arsenic varied from 95.55 to $102.70 \%$ with a mean of $99.63 \%$. These results demonstrated that the current procedure is applicable for arsenic analysis in different soil samples, with a satisfactory recovery.

Table 2. Determination and recovery of arsenic in soil samples - mine region (Bacajá -Pa).

\begin{tabular}{cccc}
\hline $\mathrm{S} \mathrm{N}^{\mathrm{o}}$ & $\begin{array}{c}\text { As initially } \\
\text { found }\left(\mu \mathrm{g} \mathrm{g}^{-1}\right)\end{array}$ & $\begin{array}{c}\text { Total As } \\
\text { found }^{\mathrm{a}}\left(\mu \mathrm{g} \mathrm{g}^{-1}\right)\end{array}$ & $\begin{array}{c}\text { Recovery } \\
(\%)\end{array}$ \\
\hline 1 & $5.00 \pm 0.020$ & $45.66 \pm 0.015$ & 101.65 \\
2 & $2.18 \pm 0.014$ & $42.50 \pm 0.013$ & 100.80 \\
3 & $3.88 \pm 0.035$ & $42.10 \pm 0.021$ & 95.55 \\
4 & $1.58 \pm 0.026$ & $41.32 \pm 0.009$ & 99.35 \\
5 & $3.79 \pm 0.033$ & $44.87 \pm 0.014$ & 102.70 \\
6 & $3.77 \pm 0.027$ & $42.06 \pm 0.015$ & 95.73 \\
7 & $3.75 \pm 0.025$ & $43.60 \pm 0.011$ & 99.63 \\
8 & $4.00 \pm 0.010$ & $44.66 \pm 0.004$ & 101.65 \\
\hline
\end{tabular}

a - Mean of three replicate analyses

Table 1. Recovery of arsenic $(2 \mu \mathrm{g})$ in the presence of diverses elements $(\lambda=$ $560 \mathrm{~nm})$.

\begin{tabular}{lccccccc}
\hline & & \multicolumn{2}{c}{ Recovery (\%) proportion } & & & \multicolumn{2}{c}{ Recovery (\%) proportion } \\
\cline { 3 - 4 } \cline { 7 - 8 } Ion & Used as & $1: 1$ & $1: 25$ & Ion & Used as & $1: 1$ & $1: 25$ \\
\hline $\mathrm{Al}$ & $\mathrm{AlCl}_{3}$ & 98.54 & 98.18 & $\mathrm{Hg}$ & $\mathrm{HgCl}_{2}$ & 135.86 & 146.20 \\
$\mathrm{Ag}$ & $\mathrm{Ag}_{2} \mathrm{SO}_{4}$ & 98.67 & 105.00 & $\mathrm{Mo}$ & $\left(\mathrm{NH}_{4}\right)_{6} \mathrm{Mo}_{7} \mathrm{O}_{24}$ & 99.98 & 104.09 \\
$\mathrm{Au}$ & $\mathrm{AuCl}_{3}$ & 97.24 & 108.11 & $\mathrm{~N}$ & $\mathrm{NaNO}_{3}$ & 103.07 & 110.34 \\
$\mathrm{Bi}$ & $\mathrm{BiCl}_{3}$ & 98.87 & 107.44 & $\mathrm{P}$ & $\mathrm{K}_{2} \mathrm{HPO}_{4}$ & 94.99 & 110.06 \\
$\mathrm{Cd}$ & $\mathrm{CdCl}_{2}$ & 101.55 & 96.54 & $\mathrm{~Pb}$ & $\mathrm{PbSO}_{4}$ & 96.60 & 100.33 \\
$\mathrm{Co}$ & $\mathrm{CoCl}_{2}$ & 100.41 & 103.33 & $\mathrm{Pt}$ & $\mathrm{H}_{2} \mathrm{PtCl}_{6}$ & 69.31 & 33.00 \\
$\mathrm{Cr}$ & $\mathrm{CrCl}_{6}$ & 102.26 & 92.96 & $\mathrm{~S}$ & $\mathrm{Na}_{2} \mathrm{~S}$ & 98.38 & 109.20 \\
$\mathrm{Cu}$ & $\mathrm{CuCl}_{2}$ & 99.11 & 97.84 & $\mathrm{Sb}$ & $\mathrm{SbCl}_{3}$ & 145.88 & 156.18 \\
$\mathrm{Fe}$ & $\mathrm{FeCl}_{3}$ & 99.42 & 95.64 & $\mathrm{Se}$ & $\mathrm{SeO}_{2}$ & 97.08 & 87.37 \\
$\mathrm{Ge}$ & $\mathrm{GeO}_{2}$ & 125.75 & 168.48 & $\mathrm{Te}$ & $\mathrm{TeO}_{2}$ & 100.83 & 109.05 \\
\hline
\end{tabular}


Table 3. Comparison with other methods.

\begin{tabular}{cccccc}
\hline$S N^{\circ}$ & References & $\begin{array}{c}\text { Wavelength max } \\
(\mathrm{nm})\end{array}$ & $\begin{array}{c}\text { Limit of detection } \\
\left(\mu \mathrm{g} \mathrm{ml^{-1 }}\right)\end{array}$ & $\begin{array}{c}\text { Repeatability } \\
(\%)\end{array}$ & $\begin{array}{c}\text { molar absortivity } \\
10^{4} \mathrm{l} \mathrm{mol}^{-1} \mathrm{~cm}^{-1}\end{array}$ \\
\hline 1 & {$[12]$} & 530 & 1.0000 & 13.00 & 1.50 \\
2 & {$[22]$} & 520 & - & 7.00 & 1.30 \\
3 & {$[23]$} & 510 & 0.0060 & - & 1.40 \\
4 & {$[24]$} & 525 & 0.0034 & 1.43 & - \\
5 & {$[25]$} & 612 & 0.0040 & 3.50 & - \\
6 & {$[26]$} & 620 & 0.0300 & $\leq 11.00$ & 13.10 \\
7 & {$[27]$} & 660 & 0.0013 & - & - \\
8 & Present method & 560 & 0.0014 & 1.46 & 24.50 \\
\hline
\end{tabular}

\section{Comparison with other methods}

The present Br-PADAP method is a very sensitive and simple form for the indirect determination of arsenic in soils, when compared with other spectrophotometric methods (Table 3 ). Limit of detection, repeatability and molar absorptivity of this method showed to be more effective than SDDC method, and other mentioned methods.

\section{Conclusions}

The Br-PADAP method for arsenic determination in soil samples showed more effective analytical results than other known methods. The criti- cal variable was the effect of Br-PADAP and EDTA amount. It was found that antimony (III), mercury (II), germanium (IV), platinum (IV) interferes at all proportions but they are removed by the EDTA. This method can be applied for soil samples analysis with good recovery, repeatability and accuracy.

\section{Acknowledgements}

The authors acknowledge the financial support of CNPq, FINEP and CAPES.

Received 09 May 2008

Accepted 07 July 2008

S. F. P. Pereira; S. L. C. Ferreira; G. R. Oliveira; D. C. Palheta; B. C. Barros. Determinação espectrofotométrica de arsênio em amostras de solo usando 2-(5-bromo-2-piridilazo)-5-di-etilaminofenol (Br-PADAP)

Resumo: Um novo método, simples e sensível para a determinação de arsênio em solo é proposto neste trabalho. Este método é baseado na redução de prata (I) e ferro (III) pela arsina seguida da reação de complexação do ferro (II) com o reagente espectrofotométrico 2-(5-bromo-2-piridilazo)-5-di-etilaminofenol (Br-PADAP). A determinação de arsênio apresentou uma sensitividade de Sandell de $3.1 \times 10^{-4} \mathrm{~cm}^{-2}$, foi linear na faixa de $0.1 \mu \mathrm{g} \mathrm{ml}^{-1}$ to $2.0 \mu \mathrm{g} \mathrm{ml}^{-1}\left(\mathrm{r}_{560}=0.9995\right)$, apresentou uma absortividade molar de $2.45 \times 10^{5}$ $1 \mathrm{~mol}^{-1} \mathrm{~cm}^{-1}$ e um limite de detecção de $1.4 \mathrm{ng} \mathrm{ml}^{-1}$ (3s) estes dados foram obtidos para $10 \mathrm{ml}$ de amostra. A seletividade foi melhorada com o uso de EDTA com agente mascarante. O método proposto foi aplicado na determinação do arsênio na presença de outros íons e em amostras de solo. Os resultados revelaram que antimônio (III), mercúrio (II), germânio (IV), platina (IV) interferem na análise em todas as proporções analisadas. As interferências podem ser facilmente removidas pelo uso do EDTA. A precisão e a exatidão deram resultados satisfatórios, com desvio padrão relativo abaixo de 5\%. As recuperações de arsênio em solo variaram de 95,55 a 102,70\% com uma média de 99,63\%. Estes resultados demonstraram que o método proposto é aplicável para a análise do arsênio em diferentes amostras de solo.

Palavra-chave: Determinação de arsênio; Br-PADAP; espectrofotometria; solo. 


\section{References}

[1] J. Bech, C. Poschenrieder, M. Llugany, J. Barceló et al. Arsenic and heavy metal contamination of soil and vegetation around a copper mine in Northern Peru. The Science of the Total Environment 203 (1997) 83-91.

[2] B. J. Alloway Ed. Heavy Metals in Soils, Blackie, Glasgow, (1990) p 83.

[3] D.C. Adriano Trace Elements in the Terrestrial Environment, Springer-Verlag, New York (1986) p 533.

[4] WHO World Health Organization Environmental Health Criteria 224, Arsenic and Arsenic Compounds, 2nd ed., Geneva (2001) p 123.

[5] J.S. Tsuji, M.D.V. Kerkhove, R.S. Kaetzel et al. Evaluation of Exposure to Arsenic in Residential Soil Environmental Health Perspectives 113 (2005) 1735-1740.

[6] H. Narasaki, J.Y. Cao Determination of Arsenic and Selenium by Hydride Generation Atomic Absorption Spectrometry Using a Gas-Liquid Separator and a Dehydration Trap Microchemical Journal 53 (1996) 18-25.

[7] M. Islam, S. Islam, S. Latif Detection of Arsenic in Water, Herbal and Soil Samples by Neutron Activation Analysis Technique Bulletin of Environmental Contamination and Toxicology 79 (2007) 327-330.

[8] A. Väisänen, R. Suontamo, J. Silvonen et al. Ultrasoundassisted extraction in the determination of arsenic, cadmium, copper, lead, and silver in contaminated soil samples by inductively coupled plasma atomic emission spectrometry Analytical and bioanalytical chemistry 373 (2002) 93-97.

[9] M. Bettinelli, U. Baroni, N. Pastorelli Analysis of coal fly ash and environmental materials by inductively coupled plasma atomic emission spectrometry: comparison of different decomposition procedures. J Anal Atom Spectrom 2 (1987) 485-489.

[10] S. Karthikeyan, T. P. Rao, C. S. P. Iyer Determination of arsenic in sea water by sorbent extraction with hydride generation atomic absorption spectrometry Talanta 49 (1999) 523 530.

[11] F.B. Martí, F.L. Conde, S.A. Jimeno, J.H. Méndez Quimica Analitica Cualitativa. Madri, Paraninfo (1985) p 1050.

[12] M.H. Arbab-Zavar, M. Hashemi Evaluation of electrochemical hydride generation for spectrophotometric determination of As (III) by silver diethyldithiocarbamate Talanta 52 (2000) 1007-1014.

[13] American Public Health Association, American Water Works Association and Water Pollution Control Federation. Standard Methods for the Examination of Water and Wastewater. 13th Ed., Washington (2005) p 1368.

[14] R.H. Merry, B.A. Zarcinas Spectrophotometric determi- nation of arsenic and antimony by the silver diethyldithiocarbamate method Analyst 105 (1980) 558-563.

[15] V. Vasak, V. Sedivec Colorimetric determination of arsenic. Chem.Listy 46 (1952) 341-344.

[16] F. Wei, Q. Song, F. Yin, N. Shen Spectrophotometric determination of iron in alumi-nium alloys using 2-(5-bromo2-pyridylazo)-5-diethylaminophenol Mikrochimica Acta 80 (1983) 17-21.

[17] A.C.S. Costa, S.L.C. Ferreira, M.G.M. Andrade, I.P. Lobo Simultaneous spectrophotometric determination of nickel and iron in copper-base alloy with bromo-PADAP Talanta 40 (1993) 1267-1271.

[18] S.L.C. Ferreira, M.L.S. Bandeira, V.A. Lemos, H.C. Santos, A.C.S. Costa, D.S. Jesus Sensitive spectrophotometric determination of ascorbic acid in fruit juices and pharmaceutical formulations using 2-(5-bromo-2-pyridylazo)-5-diethylamino- phenol (Br-PADAP) Fresenius J Anal. Chem. 357 (1997) 1174-1178.

[19] J.R. Knechtel, J.L. Fraser Preparation of a stable borohydride solution for use in atomic absorption studies Analyst 103 (1978) 104-105.

[20] A.C.S. Costa, L.S.G. Teixeira, H.V. Jaeger, S.L.C. Ferreira Spectrophotometric determination of vanadium(IV) in the presence of vanadium(V) using Br-PADAP. Mikrochim. Acta 130 (1998) 41-45.

[21] B.R. Figueiredo, R.P. Borba, R.S. Angélica Arsenic occurrence in Brazil and human exposure Environmental Geochemistry and Health 29 (2007) 109-118.

[22] J.F. Kopp 1-Ephedrine in chloroform as a solvent for silver diethyldithiocarbamate in the deter-mination of arsenic Anal Chem 45 (1973) 1786-1787.

[23] P.K. Gupta, P.K. Gupta Microdetermination of arsenic in water, spectrophotometrically, by arsine-silver diethyl-dithiocarbamate-morpholine-chloroform system Mic Journal 33 (1986) 243-251.

[24] A. Afkhami, T. Madrakian, A.A. Assl Kinetic spectrophotometric determination of trace amounts of As(III) based on its inhibitory effect on the redox reaction between bromate and hydrochloric acid Talanta 55 (2001) 55-60.

[25] K. Morita, E. Kaneko Spectrophotometric Determination of Arsenic in Water Samples Based on Micro Particle Formation of Ethyl Violet-Molybdoarsenate Analytical Sciences 22 (2006) 1085-1089

[26] A.M. Kolesnikova, A.I. Lazarev Spectrophotometric determination of arsenic in copper- and nickel-base alloys by using iodonitrotetrazolium Zh Anal Khim 46 (1991) 169-174 [27] S. Kundua, S. K. Ghosha, M. Mandala et al. Spectrophotometric determination of arsenic via arsine generation and in-situ colour bleaching of methylene blue (MB) in micellar medium Talanta 58 (2002) 935-942. 